TILTAI, 2016, 1, 97-103, ISSN 1392-3137 (Print), ISSN 2351-6569 (Online)

\title{
SOCIAL AND PEDAGOGICAL CONDITIONS OF REHABILITATION OF STUDENTS WITH SPECIAL NEEDS
}

\author{
Nataliya Hitun \\ Lutsk institute of human development of University "Ukraine"
}

\begin{abstract}
The article analyzes the social and pedagogical conditions of rehabilitation of students with special needs. The attention is focused on the peculiarities of their integration in educational environment and on the support system of these students in Lutsk institute of human development of Open international university of human development "Ukraine".

KEY WORDS: rehabilitation, student with special needs, integration, support model, social adaptation.
\end{abstract}

\begin{abstract}
Anotacija
Straipsnyje analizuojamos studentų, turinčių specialiujų poreikių, socialinės ir pedagoginės reabilitacijos sąlygos. Dėmesys sutelktas ties jų integracijos ị edukacinę aplinką ypatumais ir paramos sistemos vystymu bei tobulinimu.

PAGRINDINIAI ŽODŽIAI: reabilitacija, studentai, turintys specialiųų poreikių, integracija, paramos modelis, socialinè adaptacija.
\end{abstract}

DOI: http://dx.doi.org/10.15181/tbb.v73i1.1267

\section{Introduction}

In 2008 Ukraine joined the UN Disabled People Rights Convention, aimed at full ensuring the rights and freedoms of all people with disabilities and, what was very significant, at prevention of all forms of discrimination of people with disabilities. States that have ratified the Convention are obliged to bring their national legislation into the line with international standards. Therefore, for Ukraine as independent democratic state, special importance acquires solution of the number of urgent social problems concerning people with disabilities.

Unfortunately in Ukraine historically has been formed the situation, where people with disabilities remained socially unprotected and even, to some extent, isolated from socium for a long time, and open discussion of the problems concerning disability was unpopular in society. Today in Ukraine notable changes took place: social providing, education and social work with disabled persons, which are based on the necessity to provide them with equal opportunities in realization of the rights and freedoms in all spheres of society.

The aim of the article: elucidation of social and pedagogical conditions of rehabilitation of students with special needs in the process of education in Lutsk 
institute of human development of Open international university of human development "Ukraine".

Analysis of researches and publications. In recent years, one of the most debatable problems of education of disabled youth is definitely integration. By integration is understood the involvement of disabled people into the society as equal its members, who actively participate in all spheres of life activity. The science determines different ways of integration, such as studying with correctional direction, training and education aimed at mastering the cultural and spiritual values by disabled people, and also organization of their active participation in all spheres of life activity (Малофеев, 1996, с. 46). The integrated form of education in higher educational establishments implies joint education of students with special needs with other students. This form of education recognizes the equal rights of people with disabilities to get education and requires the equal opportunities policy implementation. Teaching and education of students with disabilities are carried out in integrated groups, which may be considered as certain microenvironment.

Materials of publications of foreign and domestic scientists, in particular, P. Evans, L. Neumann, R. Nemov, M. Pevzner, R. Boskys, N. Shmatko, T. Pelymska, B. Preobrazhenskyi, I. Chani, give opportunity to state about the problems of professional education development, about the similar development trends, about the same doubts, about the similar models of integrated education, but about the different conditions of their use both abroad and in Ukraine. Scientists are concerned on the problems of integrated education of children with severe disorders, on the problem of lessons structure in integrated education and the role of the teacher at these lessons, the problem of social acceptance of integrated children and others.

\section{Connection with important scientific and practical tasks}

In view of Ukraine's entry into the single European educational space, the necessity to improve the mechanism of meeting the educational needs of disabled people arises. In paragraph 5 of Article 24 of the Disabled People Rights Convention is stated, "states parties ensure that people with disabilities will be able to access general higher education, professional training (...) without discrimination and on equal basis with others"1. Ministry of Education and Science of Ukraine actively introduce international practices for quality reform of education in this direction. In particular, in 2008 in the Ministry of Education and Science of Ukraine held the joint meeting of the Council on issues of disabled people education at the Ministry of Education and Science, Ministry of Labor and the Coordination Council on issues of preparation and carrying out the experiment on organization

\footnotetext{
Website: www.un.org.ua.
} 
of integrated education of persons with special educational needs in higher educational institutions of III-IV levels of accreditation. The experiment involved 9 educational establishments, including the Open international university of human development "Ukraine".

Lutsk institute of human development as structural unit of Open international university of human development "Ukraine" - the only institution of higher education of integrated type, open to youth of different preparation level, differentiated social opportunities and various health statuses, which voluntarily undertook the mission to teach people with special needs. The institute has accumulated the unique experience of organization of study and education process of disabled youth in integrated groups (in general student flow), where studied more than 200 students with disabilities during 15 years of establishment's existence. Wide range of specialties in Lutsk institute of human development gives them opportunity for self-determination and self-realization, depending on individual abilities and needs. And the number of "special" students, who wish to obtain higher education, is growing every year.

For realization of social model of education of disabled people, two conditions were met in the institute. Firstly, integration models of education of disabled people at all stages of their training and education were introduced. Secondly, the functioning support model of learning process disabled people and their integration into society was created. Establishing certain social and pedagogical conditions of rehabilitation of given contingent of students during training and profession mastering is possible due to the activity of the Department of rehabilitation support of education, in which stuff coordinately work specialists of different profiles: doctors, teachers, psychologists, social workers and rehabilitators.

Important fact is that social workers' training is carried out directly in Lutsk institute of human development of University "Ukraine". Training of specialists, who are able to ensure providing of social services in the social sphere, performs the Department of social work, which aim is training of highly qualified specialists by introducing innovative models, applied methods of providing social services. The department consists of candidates of scientists, associate professors and practical experts of social work, who are trainers of social work specialists, with significant experience of participation in charitable funds and projects.

Returning to the Department of rehabilitation support of education, which functions in institute, it is worth mentioning, that the objective of the department activity is creation of integral system of medical, social and professional rehabilitation of disabled people in the period of studying, and also after its completion.

It is clear, that every student with disability has certain peculiarities and limitations that impede learning process. In work with such people, special methods, 
educational technologies and adaptive technical means should be promoted in the training and educational process. As a rule such students are very curious and diligent, but have some problems: gaps in knowledge, increased fatigue, isolation, low self-esteem, vulnerability. Herewith their pace of education must not be slowed down nor may be reduced the numbers of classes, because it decreases the quality of professional training. Therefore, the support system of education, comprehensive psycho-social help and support is introduced. The efforts of pedagogues are primarily aimed at creation of comfortable conditions, favorable psychological climate in integrated academic groups, and humanistic organization of relationships, providing the optimal regime of study, work, leisure and recreation of institute students. Moreover, creation of equal opportunities is achieved by introduction of personally oriented education, developmental education and pedagogy of cooperation.

Having already certain experience handling in the collective, where students with special needs study, healthy students indicate, that success of integration of disabled people is mostly dependent on the social environment where they are located.

The adaptation process is interconditioned, so not only disabled people should develop the qualities of socialized personality in themselves, actively include into the life of the group, collective, but also the group should go the way of adaptation to the special needs of disabled person in studying, with understanding to accept its situation, to define active life position, to include into the integration processes. The studying and educational process should consider personality as the system focus of social and of pedagogical influence, as the start and the end points of multi-faceted process of socialization.

In their turn, students with disabilities point out, that people who have special needs do not feel inferior, but rather in university education conditions are revealed as personalities. And, as example, our students realize their life potential in different way. In institute were prepared many disabled students who worthily represented Ukraine in international sports arena. Among them there are 22 disabled sportsmen engaged in Paralympic sports, in particular, two champions and two Paralympic medalists, one Deaflympic Games champion, two world champions and one world medalist, two Europe champions, nine Ukraine champions. Such achievements are the result of cooperation with the Center of handicapped athletes of Volyn, and also the high level of organization of the educational and training process and qualitative material and technical basis of university.

At the beginning of study of disabled students is not so optimistic situation observed. The results of sociological studies show that students during the initial examination along with lowered self-esteem of social sphere and socio-economic 
aspect of life quality, the adaptive and personality characteristics were reduced. These are deviations that give grounds to believe, that the process of social and psychological adaptation of students with special needs is hampered by emotional discomfort, conditioned first of all by unformed ability to trust strangers and insufficient formation of own "I" image.

Success indicators of studying after the first semester showed the significant predominance of number of students with satisfactory performance. Taking into account the psychological, social, physiological and educational indicators of readiness of disabled students to study in higher educational institutions gave opportunity to formulate and to introduce the system of basic actions in their rehabilitation, for realization of which one should follow such preconditions:

- organization of educational process that meets the functional capabilities of students with special needs;

- active involvement of students into the interpersonal relations in students environment;

- accessibility of information (library, Internet);

- development of their creative activity and professional self-realization;

- use of complex health measures.

As for realization of these preconditions, in institute arranged preparation and publication of educational and methodical literature, created lectures audio records (for students with visual impairments is granted access to the mediatheque), conduction of individual lessons; from the side of healthy students valuable is group mutual help realization for disabled students; educational and methodical seminars holdings for teachers. Methods of differentiated approach to the process of education and knowledge assessment of these students are developed. During training lessons multimedia equipment, touch screen, copying devices, sound amplification systems, voice recorders, hearing aids, notebooks are used. For organization of independent work of students is important to provide them with access to the Internet resources and library funds, that implies convenient location of computer seats, catalogs and literature in reading halls.

Work with students with special needs includes conduction of psychological, pedagogical and biomedical diagnostics. Such complex examination is conducted on the basis of research laboratory of functional diagnostics and rehabilitation. Based on the survey results, complex physical rehabilitation programs are formed, aimed at compensation or restoration of violated body functions and improvement of general health status and increase of educational success of students with special needs.

Psychological rehabilitation is based on the results of diagnostics of psychological qualities, abilities and interests and envisages the solution of the range of 
identified psychological problems, namely: formation of high level self-esteem, emotional stability, improvement of communicative skills by conducting the psychological trainings and consultations, the leading idea of which - achievement of sense of psychological comfort of disabled students through the creation of favorable emotional atmosphere in the collective of the institute.

Social rehabilitation lies in engagement of students to student government, leisure organization, summer holidays, festivals, exhibitions, art contests, sports competitions, recreational programs; organization of work with parents; conducting of seminars, discussions. This work strengthens the faith of young people with disabilities in success achievement in different life collisions.

In institute functions Volyn regional branch of all-Ukrainian youth public organization of disabled students "Gaudeamus", aim of which is protection of interests and providing assistance of disabled students in realizing their legitimate social, cultural, professional, educational and other rights, promotion the development of educational activity in the field of education of students with disabilities.

In 2014 the Department of rehabilitation support of education in cooperation with Volyn regional association of disabled children "Special child" realized two competitive projects on youth problems: first project "Summer gathers friends" - of the problems of meaningful leisure, recreation and rehabilitation of young people with special needs; the second project "Social and psychological support of adolescents with physical disabilities".

Topical issue of social adaptation of disabled students to the study in higher education institutions is technical provision and equipment of facilities: in particular, in institute convenient entrances, ramp, special toilets, elevators, restrooms and psychological relaxation rooms are envisaged.

Teachers believe that the most urgent question of education students with special needs is psychological and pedagogical readiness to study in higher education institution. That was key question: can young person with special needs obtain higher education and find employment successfully? - was the leitmotif of the round table "Choose your future", held jointly with Volyn regional association of disabled children "Special child" on occasion of the International day of disabled people on Dec. 3, 2014.

\section{Conclusions}

Thus, Lutsk institute of human development of Open international university of human development "Ukraine" in general and the Department of rehabilitation support of education and the Department of social work in particular, realize the program of inclusive education of students with special needs and believe that for 
provision of educational services in educational establishment of integrated type which is our institute, should be carried out in combination of organizational, social, psychological, medical, rehabilitation and physical health improving services.

Disabled people are integral part of our society and therefore have every right to obtain quality education that will enable them to realize their life potential. Such approach leads to the creation of favorable social background, friendly, empathic, not focusing on obsessive attention to disability, but one, that raises equal requirements to acquire knowledge, develop professional abilities and skills. Achieve this is possible through individual, differentiated approach to each student, meeting the special needs in barrier-free architecture, information, auxiliaries, social relationships, special financing and rehabilitation.

Important role is assigned to such accompanying conditions as public readiness to the perception of disabled people as full members of society and the state policy implementation to introduce integrated education.

Received 20151220 Approved for publishing 20160307

\section{Bibliography}

Лузік, Е. (2006). Креативність як критерій якості в системі підготовки фахівців профільних ВНЗ України. Вища освіта Украӥни, № 3, с. 76-82.

Малофеев, Н. Н. (1996). Специиальное образование в России и за рубежсом. Москва: ИНФРА-М.

Скнар, О. (2006). Модернізація і методів навчання студентів у контексті кредитно-модульної систем. Вища школа, № 3, с. 33-45.

Таланчук, П. М., Кольсенко, К. О., Нікуліна, Г. Ф. (2004). Супровід навчання студентів з особливими потребами в інтегрованому освітньому середовищі. Киев: Соцінформ.

Чані, I. (2006). Досвід втілення положень про освіту для дітей з особливими потребами в краӥнах Центральної Європи. Киев. 
